\title{
MEANINGS OF INTERNAL MARKETING BUILT BY THE NURSES OF A BRAZILIAN UNIVERSITY HOSPITAL
}

\author{
Significados de marketing interno para enfermeiros de um hospital \\ universitário brasileiro
}

\section{Significados de marketing interno para enfermeros de un hospital universitario brasileño}

Rodrigo Nonato Coelho Mendes ${ }^{1}$, Danielli Rafaeli Candido Pedro ${ }^{2}$, Larissa Gutierrez de Carvalho Silva ${ }^{3}$, João Lucas Campos de Oliveira 4 , Maria do Carmo F. Lourenço Haddad ${ }^{5}$

\section{How to cite this article:}

Mendes RNC, Pedro DRC, Silva LGC, Oliveira JLC, Haddad MCFL. Meanings of internal marketing built by the nurses of a brazilian university hospital.2020 jan/dez; 12:1110-1115. DOI:http://dx.doi.org/0.9789/21755361.rpcfo.v12.8004.

\begin{abstract}
Objective: The study's main purpose has been to understand the meanings of internal marketing built by nurses working in a Brazilian university hospital from the perspective of symbolic interactionism. Methods: This qualitative study was perforemd through interviews with ten registered nurses, in which a previous concept of internal marketing was presented. Results: The speech analysis permitted the participants' statements to be organized in the category "Building the meanings of internal marketing expressed by nurses", which determined the following three subcategories or meaning cores: "The meaning of internal marketing permeated by leadership", "Internal marketing and the motivational meaning", and "Quality of care as a product of internal marketing". A conceptual map showing the meanings was also developed. Conclusion: Internal marketing proved to be applicable to the nursing context, with meanings related to the quality of care by promoting employees' motivation and satisfaction, making them pursue organizational goals. Head nurses can use internal marketing to attract and retain nursing human resources and improve the organization's quality and performance.
\end{abstract}

Descriptors: Nursing, marketing, health service marketing.

1 Nursing Graduate by the Universidade Federal do Vale do São Francisco (UNIVASF), Specialists' Degree in Nursing Services Management by the UEL, Specialists' Degree in Occupational Nursing by the Centro Universitário Internacional (UNINTER), PhD student in Science at Universidade de São Paulo (USP), Brazil.

2 Nursing Graduate by the Universidade Estadual do Oeste do Paraná (UNIOESTE), Specialists' Degree in Nursing Management in Medical and Surgical Clinics by the UNIOESTE, MSc student in Nursing at Universidade Estadual de Londrina (UEL), Brazil.

3 Nursing Graduate by the UEL, Specialists' Degree in Nursing Assistance for Wounded Patients by the UEL, Specialists' Degree in Nursing Services Management by the UEL, MSc in Nursing by the Universidade Estadual de Maringá (UEM), PhD in Science by the USP, Professor at Universidade Estadual de Londrina (UEL), Brazil.

4 Nursing Graduate by the UNIOESTE, MSc in Nursing by the UEM, PhD in Nursing by the UEM, Former Postdoctoral Researcher at UEL, Associate Professor at Universidade Federal de Mato Grosso (UFMT), Brazil..

5 Nursing Graduate by the UEL, MSc in Histology by the UEL, PhD in Nursing by the USP, Assistant Professor at UEL, Brazil. 


\section{RESUMO}

Objetivo: conhecer os significados de marketing interno para enfermeiras de um hospital universitário brasileiro na perspectiva do interacionismo simbólico. Metodologia: entrevistas qualitativas foram realizadas com dez enfermeiras, nas quais apresentava-se um conceito prévio de marketing interno. Resultados: a análise das falas foi organizada na categoria "construindo significados de marketing interno", com os temas: (1) o agir frente ao símbolo marketing interno e o significado estratégico, (2) o marketing interno e o significado motivacional, e (3) qualidade do cuidado como produto do marketing interno. Foi elaborado também um mapa conceitual com os significados produzidos. Conclusão: o marketing interno mostrou-se aplicável para o contexto de enfermagem, com significados relacionados à qualidade assistencial, por meio da motivação e satisfação dos colaboradores, voltando-os para as metas organizacionais Enfermeiros líderes podem utilizar o marketing interno para atrair e reter recursos humanos de enfermagem, e melhorar a qualidade e o desempenho da organização.

Descritores: Enfermagem; Marketing; Marketing de serviços de saúde.

\section{RESUMÉN}

Objetivo: conocer los significados de marketing interno para enfermeras de un hospital universitario brasileño en la perspectiva del interaccionismo simbólico. Metodología: entrevistas cualitativas fueron realizadas con diez enfermeras, en las cuales se presentaba un concepto previo de marketing interno. Resultados: El análisis de los discursos se organizó en los "significados de marketing interno de construcción" con los siguientes temas: (1) que actúa contra el símbolo de marketing interno y la importancia estratégica, (2) la comercialización interna y el significado de motivación, y (3) calidad del cuidado como producto del marketing interno. Se elaboró también un mapa conceptual con los significados producidos. Conclusión: el marketing interno se mostró aplicable para el contexto de enfermería, con significados relacionados a la calidad asistencial, por medio de la motivación y satisfacción de los colaboradores, volviéndolos a las metas organizacionales. Enfermeros líderes pueden utilizar el marketing interno para atraer y retener recursos humanos de enfermería, y mejorar la calidad y el desempeño de la organización.

Descriptores: Enfermería; Mercadeo; Comercialización de los Servicios de Salud.

\section{INTRODUCTION}

In the health sector, there is the ongoing challenge of reconciling cost control with service quality, especially in an increasingly dynamic and competitive market. This has motivated health facility managers to seek customer satisfaction, as well as their employees' commitment. This is why the customers' internal and external perceptions tend to be a consequence of whether or not their expectations regarding the service they seek are met. ${ }^{1}$

In hospitals, nursing professionals keep in constant contact with clients because they care for numerous people constantly. They become key actors in the patients' experiences and satisfaction with the service provided. ${ }^{2}$ In this scope, it is evident that nursing performance has an impact on the quality of the health care final product since the patient's experience on care is notoriously one of the main indicators of organizational results. ${ }^{3}$

Despite the relevance of nursing to improving the patients' satisfaction and experience, ${ }^{2,3}$ it is known that many organizations across the world have difficulties in retaining nursing human resources, because it is a professional area with often workload, in addition to the great physical and emotional exposure of employees. This tends to increase absenteeism and team turnover rates, which are important indicators for people management. ${ }^{4}$

Attracting and retaining nursing human resources should be a priority concern of health systems. ${ }^{4-5}$ In the hospital context, much emphasis has been placed on the so-called "magnet hospitals", which are organizations with strategies to retain talent, among other systemic benefits. ${ }^{5}$

Internal marketing is a strategy that can be used to guide head nurses and other health managers so that the difficulty in attracting and retaining workers can be alleviated. Proposed in the 1970s, internal marketing is a human resource management strategy that seeks the satisfaction and motivation of employees, allowing them to focus on the organization's objectives. ${ }^{6-9}$

In 2000, authors from the marketing area had reviewed 20 years of literature on the subject and concluded that internal marketing can be understood as a means of managing people to meet organizational goals. ${ }^{10}$ The reason is that it is an ongoing effort to reduce organizational resistance to change and to align, motivate and integrate workers for the effective implementation of corporate and functional strategies. ${ }^{10}$

In the context of nursing, a study carried out in Taiwan analyzed internal marketing from the nurses' perspective. It was found that this strategy makes it possible to cultivate a positive corporate culture, encouraging loyalty and retention of professionals. As a result, time and cost savings increase, which can be used to provide nursing professional training to improve work quality. ${ }^{11}$

It is worth mentioning that the Organization and Evaluation of Policies, Programs and Services is one of the priority areas of the National Research Priorities Agenda of the Brazilian Ministry of Health because of the study of "forms of work, knowledge and technology management from an organizational and institutional point of view". ${ }^{12}$ Therefore, the importance of internal marketing for global nursing and health systems, the fact that little research on this subject has been conducted in Brazil, and the possible improvements in people management justify the development of this study in terms of scientific and social aspects.

Given the obvious scientific incipience in the subject, knowing the meaning(s) of internal marketing for nurses is essential to identify the applicability of theoretical concepts of internal marketing to nursing practice, especially in Brazil. Thus, the following research question was developed: "what does internal marketing mean for nurses?" Therefore, the objective of this study was to understand the meanings of internal marketing for nurses working in a hospital environment.

\section{METHODS}

This is a descriptive-exploratory study with a qualitative approach was carried out with nurses working in a university hospital in the South Region of Brazil. 
The health facility had 110 nurses. Research participants were selected randomly. Initially, the first ten selected nurses were personally invited to participate in the study; in case of refusal, the next randomly selected would be invited. The study objective was achieved during the tenth interview with the saturation of reports. Five nurses refused to participate in the study. Data were collected through semi-structured, individual, and recorded interviews using a portable recorder. Furthermore, minimum data extraction was performed to characterize the nurses.

In order to foster the content of the interviews, a previous and synthetic concept of internal marketing ${ }^{9-10}$ was read and then the dialogue began by discussing the participant's meanings related to the concepts presented. Therefore, the interview began with the following guiding statement: "Tell me about what internal marketing means for you". Support questions were asked if the participant had difficulty in expressing his/her opinions.

The interviews were transcribed in full. After that, they were submitted to thematic content analysis, which comprises the following steps: pre-analysis, material exploration, and data analysis, in which inference and interpretation of the results were carried out. ${ }^{13}$ In pre-analysis, successive readings were made without data interpretation in order to determine points of interest or central ideas. In material exploration, the central ideas were grouped according to meaning. These groups, called meaning cores, were condensed thematically (according to their affinity with the content) into categories. Finally, the categorized results were interpreted. ${ }^{13}$

The interpretation of the results categorized thematically was based on symbolic interactionism. This theoretical perspective emerged at the end of the 19th century and had George Herbert Mead, who was a pioneer of interactionism ideas, as its greatest exponent. Nevertheless, the concepts were only systematized by Herbert Blumer, Mead's disciple, who introduced the term "symbolic interactionism". The principles of the theory were based on Mead's analysis: self, action, social interaction, objects, and joint action. Hence, it is a theory that deals with human behavior and social interaction. ${ }^{14,15}$

Symbolic interactionism comprises three basic premises: 1) human beings act in response to things based on their meaning. Things include everything that human beings can observe in the physical environment, such as objects, people, institutions, ideas, activities and life situations; 2) the meaning of things arises from social interactions among human beings; and 3) people manipulate and modify meanings by means of an interpretative process to deal with things throughout life. . $^{14,15}$

To guarantee the anonymity of the nurses interviewed, the statements were labeled using the letter "N" (nurse) followed by a number from 1 to 10 representing the chronological order of the interviews. Words in brackets were added to improve the reader's understanding without changing the statements' meaning.

After categorization and interpretation of the results, a conceptual map was developed, which is a theoretical strategy that enables the development of critical thinking skills.
It is a diagram intended to illustrate meanings, significant relationships, and conceptual hierarchies, being considered a tool for knowledge organization. ${ }^{16}$ In this context, a conceptual map showing the nurses' concepts of internal marketing was developed.

This study respected ethical guidelines for research with human beings and was approved under the Certificado de Apresentação para Apreciação Ética (CAAE) [Certificate of Presentation for Ethical Appreciation] No. 37894314.8.0000.5231.

\section{RESULTS}

Ten registered nurses have participated of this study, all of them being married females aged 39.8 years old on average. Furthermore, they had 16.8 years of formal education on average. One participant was a specialist, another was an MSc student, and the remaining participants held an MSc. None of the participants had another employment relationship. The analysis of the participants' statements made it possible to determine the following thematic category: "Building the meanings of internal marketing expressed by nurses".

\section{Building the meanings of internal marketing expressed by nurses}

This category emerged through speech analysis, allowing to determine the following three subcategories or meaning cores, which are meanings derived from the nurses' view of internal marketing: "The meaning of internal marketing permeated by leadership", "Internal marketing and the motivational meaning", and "Quality of care as a product of internal marketing".

\section{The meaning of internal marketing permeated by leadership}

Because it was an infrequent theme in the daily life of the nurses who participated in the research, the first interaction with the interviewees while discussing the concepts of internal marketing provoked a preliminary reaction of surprise, which was promptly replaced by a reflective attitude and search for meanings based on the participants' experiences. They initially associated the meaning of internal marketing with a strategy for influencing others in order to achieve the goals set by leaders.

"I understand internal marketing by means of the way you present your ideas and where you want to go, it's the way to stimulate people to get where you want to go. [...] I think it's what will determine the success or failure of what you want to do. (N3)

"[...] Discussing something together, it needs to be done so that everyone does what is necessary. From what you come up with and discuss in the group, it becomes more feasible to happen. (N4) 
"[...] It is to convince, motivate, and integrate the team to achieve the objectives that we [heads] want to achieve". (N5)

The participants' statements triggered the first meaning of internal marketing: a tool for leading people. Also, these statements have in common the focus on the fulfillment of tasks. However, the nurses went further in their internal marketing meanings, associating this management tool with people's motivation.

\section{Internal marketing and the motivational meaning}

By associating the interviewees' professional experiences with internal marketing, we noticed the link between the concepts read at the beginning of the interviews and the symbol "motivation for work", which was viewed as something close to professional satisfaction. In this context, professional satisfaction and motivation were expressed by the nurses, as can be seen below:

"The employee has to feel valued. He/she has to be always trying to improve himself/herself, improve his/her self-esteem". (N3)

"First of all, the person has to be happy with the service and happy with himself/herself". (N4)

"It would be a good environment to work in, people would work with more motivation. Everything would be easier". (N5)

"I think in a work environment there are little things you do for the employee, and he/she already feels more motivated, he/she feels better [...]". (N7)

The participants linked leadership to staff motivation and viewed internal marketing as a bridge to better quality care, in other words, as something that directly influences nursing outcomes.

\section{Quality of care as a product of internal marketing}

In the interviews, it was possible to notice that the process of interaction between workers and customers and between the organization and workers was considered a preponderant factor for the results of the care provided, which were decisive for the customers' satisfaction and positive perception of the service. In this sense, internal marketing was viewed as a bridge for such interaction in order to impact on the quality of nursing care.

"I think the hospital would make a huge improvement in terms of quality and customer satisfaction. [...] This will only be possible if the employee is working in peace with himself/herself". (N2)

"[...] And it's not possible for an unhappy employee to offer a quality service, if I'm unhappy, how can I offer something good to that person? There's no way". (N4)

"I think it's very important [employee satisfaction] because the employee is on the front line with the customer. The satisfied employee will provide better care for the patient, the result will be better". (N6)

The nurses referred to the team members under their leadership as people in direct contact with patients. Additionally, they associated the intrinsic factors of the individual who performs the service with the quality of the service offered, and consequent satisfaction with patients and workers.

Based on the meanings of internal marketing expressed by the nurses, it was possible to construct the conceptual map shown in Figure 1.

Figure 1 - Conceptual map illustrating the meanings of internal marketing according to the nurses' statements.

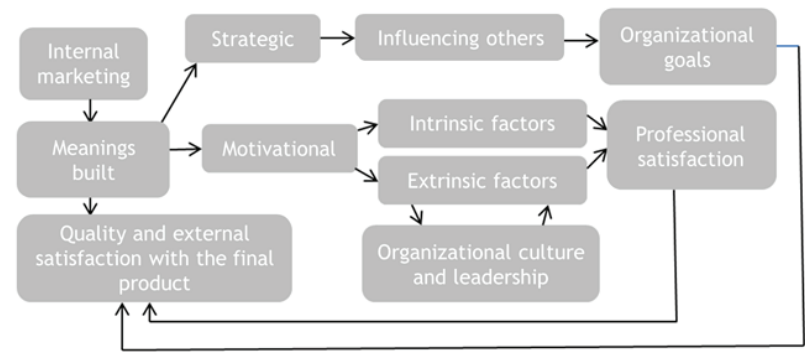

\section{DISCUSSION}

Meaning is related to the act of making sense of things or assigning importance, scope, meaning, or value to something through a word or thing. Symbols, on the other hand, represents or replaces other things, or are emblems, marks, and signs. ${ }^{17}$

By using the previous and synthetic concepts brought by the interviewer, the participant was approached by means of a first symbol, the internal marketing. This approach was based on the first premise of Blumer's theory, in which people act in response to symbols according to the meaning built by them, thus starting the process of symbolic interaction. Then, researchers and subjects found themselves in social interaction. It is an interaction among human beings with the purpose of seeking meanings. ${ }^{14,15}$

The interviews sought to determine elements of the participants' experiences, triggering interpretive processes, and in turn giving meaning to internal marketing to nurses. ${ }^{14,15}$ For this reason, it is understood that the meanings that emerged reflect the nurses' reality, despite being possibly unrelated to the formal knowledge about internal marketing. 
Considering the leadership profile, the understanding these factors has an important relationship with internal marketing because this is a people management strategy that is concerned with the organizational commitment of those under leadership by making employees take the organization objectives and values for themselves in order to help institutions to provide quality services and user satisfaction. ${ }^{18}$ In other words, nurses viewed internal marketing as a driving force to achieve previously defined goals, which is in full agreement with what is expected from nurses, who are care managers.

In this sense, we can see some statements focused on the leader, antagonizing success and failure so as to represent the act of (not) performing actions related to what the leader "wanted" to do. On the other hand, another report highlighted the focus on the group and the collective as a strategy to enhance the fulfillment of tasks.

At other times some participants demonstrated that the head's responsibility for decisions was transferred to the entire group. So, the task is not imposed by the immediate head, but it is a natural part of the job or is instituted by the organization. It is up to the group to decide how and when the tasks will be accomplished.

Then, organizational culture is the work environment in which internal marketing becomes effective, and environment, physical and organizational factors, as well as personal perceptions, give rise to meanings that allows the interpretation of reality by individuals, generating possible satisfaction with the work. ${ }^{19}$

The quality of the services provided by a health facility is an important concern because it is quality that will determine the choice, recommendation, and acknowledgment of the company by people in an increasingly competitive market and the midst of so many technological advances. ${ }^{20}$

Internal marketing can help organizations attract and retain high-skilled employees because it is concerned with how the organization's management should offer educational programs, explicitly communicate organizational perspectives, and create reward systems that improve employees' skills and satisfaction with their jobs. ${ }^{18,21}$ In this scope, the understanding of the meanings built by the nurses, which were related to motivation, is clearly in line with the basic precepts of internal marketing, and this insight can be positive for the strategy to be implemented in the nursing practice.

In order to do so, many organizations evaluate the quality of the service provided by the triad proposed by Donabedian: structure, process, and result. According to this theory, the structure includes human, economic, physical, and material normative resources. The process involves the interaction between professionals and users, considering its multiple interfaces and dimensions. The results include the final product of the service provided, analyzing the assistance provided as well as whether expectations were satisfied. ${ }^{20,22}$

In regard to the quality, it is worth reinforcing that internal marketing aims at quality and external customers' satisfaction. Nonetheless, this process occurs indirectly by promoting the satisfaction and motivation of human resources, seeking more effective work processes, and high-performance results. ${ }^{18}$ Successful results can also be interpreted from the perspective of interactionism since the meaning of things stems from previous meanings, human interactions, and multiple interpretations. In this context, customer service is an interactive process. ${ }^{14,15}$

Concerning the client satisfaction, the authors argued that it is a reflection of the commitment and professionalism of the nursing professionals, which agrees with the meanings built by the research participants. Internal marketing, according to the above-mentioned authors, is regarded as a people management tool used by organizations to educate, train, and motivate employees to provide a better service to consumers, including health services. ${ }^{23,24}$

The quality of care and the balance of costs in the health sector is a major challenge for contemporary managers. ${ }^{18}$ Internal marketing is proving to be a promising tool for supporting decision making in an increasingly competitive market, with consumers increasingly autonomous and aware of their rights. The research participants were able to assign meanings to their experiences and build the meanings of internal marketing compatible and comparable with the deeper analysis presented in the literature.

\section{CONCLUSIONS}

Bearing in mind the aforesaid, it is concluded that the meanings of internal marketing built by nurses working in a hospital environment are linked to strategic leadership, employees' continuous motivation, and quality of care as a product of internal marketing. These meanings are in line with the principles of the phenomenon under study. This is a positive contribution of this study since little research on the subject has been conducted. Moreover, the investigative process may have fostered the need for increased management of people by nurses.

It is believed that the study's maximum limitation belong to the inactive nature of the participants, which prevented a process of internal marketing implementation through research. So, this is already a sign indicating that further research should be done. Conclusively, it is believed that this study permits people management in hospital nursing to advance by promoting an innovative management tool and focusing on human capital to promote organizational benefits, a fact that might be a necessity in the near future in nursing.

\section{REFERENCES}

1. Weng HC, Chen TM, Lee WJ, Chang CS, Lin CT, Wu ML. Internal marketing and its moderating effects between service-oriented encounter and patient satisfaction. Acta Paul Enferm. 2016; 29(5):50617. Available from: http://dx.doi.org/10.1590/1982-0194201600071.

2. Aiken LH, Sloane DM, Ball J, Bruyneel L, Rafferty AM, Griffiths P. Patient satisfaction with hospital care and nurses in England: an observational study. BMJ Open. 2018; 8:e019189. Available from: http://dx.doi.org/10.1136/bmjopen-2017-019189.

3. Desborough J, Phillips C, Mills J, Korda R, Bagheri N, Banfield M. Developing a positive patient experience with nurses in general practice: An integrated model of patient satisfaction and enablement. J Adv Nurs. 2017; 74(3):564-78. Available from: http://dx.doi. org/10.1111/jan.13461. 
4. Leitão IMTdeA, Sousa FSPde, Santiago JCdosS, Bezerra IC, Morais JBde. Absenteísmo, rotatividade e indicadores de qualidade do cuidado em enfermagem: estudo transversal. Online braz j nurs. 2017; 16 (1):119-129. Available from: http://www.objnursing.uff.br/index. php/nursing/article/view/5623 16(2).

5. Petit Dit Dariel O, Regnaux JP. Do Magnet ${ }^{\circ}$-accredited hospitals show improvements in nurse and patient outcomes compared to non-Magnet hospitals: a systematic review. JBI Database System Rev Implement Rep. 2015; 13(6):168-219. Available from: http://dx.doi. org/10.11124/jbisrir-2015-2262.

6. Kim B, Lee J. Relationships between Personal Traits, Emotional Intelligence, Internal Marketing, Service Management, and Customer Orientation in Korean Outpatient Department Nurses. Asian Nurs Res. 2016; 10(1):18-24. Available from: http://dx.doi.org/10.1016/j. anr.2015.10.005.

7. Tsai Y. Learning organizations, internal marketing, and organizational commitment in hospitals. BMC Health Serv Res. 2014; 14(1). Available from: http://dx.doi.org/10.1186/1472-6963-14-152.

8. Morais IDC, Soares AM. Impacto do Marketing Interno sobre a Orientação para o Mercado em Empresas Brasileiras. Rev adm contemp. 2016; 20(2):197-215. Available from: http://dx.doi. org/10.1590/1982-7849rac2016140069.

9. Berry LL, Hensel JS, Burke MC. Improving retailer capability for effective consumerism response. Journal of Retailing.1976;52(3):3-14.

10. Azêdo DF, Alves MH. Práticas de marketing interno nas organizações de saúde e a sua influência na motivação dos colaboradores. Rev port saúde pública. 2013; 31(2):201-212. Available from: http://dx.doi. org/10.1016/j.rpsp.2013.05.003.

11. Andrade JB, Cavalcante MB, Apostólico MR. Marketing pessoal e enfermagem: projeção para visibilidade social do enfermeiro. Enf em foco. 2017; 8(1). Available from: https://doi.org/10.21675/2357707X.2017.v8.n1.946.

12. Ministério da Saúde. Secretaria de Ciência Tecnologia e Insumos Estratégicos. Agenda Nacional de Prioridades de Pesquisa em Saúde. 2015. Available from: http://brasil.evipnet.org/wp-content/ uploads/2017/07/ANPPS.pdf.

13. Bardin L. Análise de conteúdo. São Paulo: Edições 70, 2011.

14. Maniva SJ, Freitas C, Jorge MSB, Carvalho ZMF, Moreira TMM Experiencing acute stroke: the meaning of the illness for hospitalized patients. Rev esc enferm USP. 2013; 47(2):362-368. Available from: http://dx.doi.org/10.1590/S0080-62342013000200013.

15. Blumer H. Symbolic interactionism perspective and method. California.1986.

16. Bittencourt GKGD, Nóbrega MML, Medeiros ACT, Furtado LG Concept maps of the graduate programme in nursing: experience report. Rev Gaúcha Enferm. 2013; 34(2):172-176. Available from: http://dx.doi.org/10.1590/S1983-14472013000200022.

17. Luft CP. Minidicionário Luft. 22a Edição. Ática, 2013.

18. Rodrigues A, Queirós A, Pires C. A influência do marketing interno nas atitudes e comportamentos dos colaboradores: aplicação a uma organização de cuidados sociais e de saúde. Rev Port Sau Pub. 2016 34(3). Available from: http://dx.doi.org/10.1016/j.rpsp.2016.08.001.

19. Lapischies SRC, Jardim VMR, Kantorski LP. Factors associated with satisfaction at work in Psychosocial Care Centers. Rev LatinoAm de Enferm. 2014; 22(6):950-958. Available from: http://dx.doi. org/10.1590/0104-1169.3474.2500.

20. Kotler P. Marketing Management: Analysis, Planning, Implementation and Control. Prentice-Hall, 2010.

21. Garçon TL, Pupulim JSL. Qualidade do atendimento pré - hospitalar móvel de urgência na perspectiva dos profissionais. Cienc Cuid Saude. 2017; 16(4). Available from: http://dx.doi.org/10.4025/cienccuidsaude. v16i4.37306.

22. Silva ER, Hecksher SD. Qualidade do atendimento em serviços públicos de saúde. Rev Gest Saúde. 2016; 7(1). Available from: periodicos.unb.br/index.php/rgs/article/download/22002/15710.

23. Tsai Y. Learning organizations, internal marketing, and organizational commitment in hospitals. BMC Health Serv Res. 2014; 14,152. Available from: http://dx.doi.org/10.1186/1472-6963-14-15.

24. Aguiar LK, Siman AG, Brito MJM. O endomarketing como estratégia de gestão de pessoas em saúde: um estudo de caso. Rev enferm UFPE on line. 2013; 7(9):5490-9. Available from: http://dx.doi.org/10.5205/ reuol.3529-29105-1-SM.0709201317.

Received in: 09/08/2018

Required revisions: 19/12/2018

Approved in: 15/02/2019

Publicado em: 24/08/2020

Corresponding author

Danielli Rafaeli Candido Pedro

Address: R. Sidrack Silva, 116, Aeroporto

Londrina/PR, Brazil

Zip code: $86.038-560$

Email address: danirafaeli@hotmail.com

Disclosure: The authors claim to have no conflict of interest. 